\title{
ATTEMPTS TO ESTABLISH COLONIES OF THE PURPLE MARTIN IN NEST BOXES IN CALIFORNIA: FIRST SUCCESS AND EVALUATION OF FAILURES
}

DANIEL A. AIROLA, Northwest Hydraulic Consultants, 2600 Capitol Ave., Suite 140, Sacramento, California 95816; dairola@nhcweb.com

STAN KOSTKA, Western Purple Martin Working Group, 28603 Kunde Rd., Arlington, Washington 98223

CORINNA ELWOOD, 5450 Monterey Hwy, SPC 165, San Jose, California 95111

ABSTRACT: The Purple Martin (Progne subis), designated a species of special concern by the California Department of Fish and Wildlife, has been reported using nest boxes in California only a few times, in contrast to its extensive adoption of nest boxes in Oregon, Washington, and British Columbia and long-term use of them in eastern North America. We installed and monitored nest boxes and artificial gourds at Shelter Cove along California's northwest coast, where a substantial population of nesting martins is threatened by loss of snags. We placed three nest boxes at one nesting area in 2002, and, after the martins used two boxes in 2007, we added 15 boxes and seven gourds in groups at six other sites early in 2008. From 2008 to 2011 , martins used up to 11 boxes and two gourds, as well as nesting in snags, utility poles, and buildings. We monitored their nesting success in 2008, when three of five occupied boxes successfully fledged young. We also installed boxes or advised on attempts to establish box-nesting colonies at six other sites elsewhere in northern California, none of which were successful. Reasons for failure may include too great a distance from the nearest source population, improper placement, and the martins' unfamiliarity with a novel type of nest site. Our experiment at Shelter Cove represents the first successful use of nest boxes designed and placed for Purple Martins in California and suggests boxes may be an effective tool for securing and recovering Purple Martin populations in California.

In western North America, populations of the Purple Martin (Progne subis) are small and declining in many areas (Tautin et al. 2009). The species' population and geographic range have contracted in California, where the martin is recognized a species of special concern (Airola and Williams 2008). Suggested major causes of the decline include loss of nest sites (primarily woodpecker-excavated holes in dead trees), competition for nest sites with the non-native European Starling (Sturnus vulgaris), and pesticide-induced decline in insect prey (Airola and Grantham 2003, Airola and Williams 2008, Airola et al. 2014).

In eastern North America, Purple Martins have a history of using humansupplied sites extending back to precolonial times (Brown and Tarof 2013). Martins there have undergone a "cultural shift," now nesting in nest boxes and gourds almost exclusively. In the West they have adopted nest boxes relatively recently, presumably because of western populations' shorter and less extensive exposure to human-supplied nest sites. Nest boxes have been widely introduced and adopted in large areas of British Columbia, Washington, and Oregon over the last 40 years, resulting in dramatic increases in previously depleted martin populations (Kostka and McAllister 2005, Tautin et al. 2009, Cousens and Lee 2012). Currently, the proportion of the Pacific Northwest population estimated to be breeding in nest boxes is high: $50 \%$ 
in Oregon (Horvath 1999), 90\% in Washington (Kostka and McAllister 2005), and 100\% in British Columbia (Cousens and Lee 2012). In the Pacific Northwest most boxes have been sited where martins were nesting in marine pilings, on which the boxes are often mounted (Kostka and McAllister 2005, Cousens and Lee 2012). The martins' prevalence of nest-box use in the Pacific Northwest has not caused the species to abandon natural sites. Rather, the increased availability of nest sites has dramatically augmented the previously depleted population (Horvath 1999, Kostka and McAllister 2005, Cousens and Lee 2012).

We know of no previous concerted effort to establish Purple Martin colonies in nest boxes in California, perhaps because population declines there were less extensive and well documented than in the Pacific Northwest. Martins are known to have nested in boxes in California only rarely, in boxes erected for other species (Williams 1998). Establishing nest-box colonies could provide an important tool for stabilizing and recovering Purple Martin populations in California as it has in the Pacific Northwest. Nest-box programs have demonstrated success for other depleted cavity-nesting species in North America, including the Eastern Bluebird (Sialia sialia; Gowaty and Plissner 2015), Western Bluebird (Sialia mexicana; Guinan et al. 2008), and Barn Owl (Tyto alba; Marti et al. 2005).

Kostka initiated the first California nest-box program at Shelter Cove, Humboldt Co., in 2002 by placing boxes near existing nesting snags at one site. After Purple Martins used two of the boxes in 2007, Airola and Kostka installed additional nest boxes and artificial gourds there in 2008, and Elwood surveyed the martins' use of nest boxes and other substrates in 2008, which was reported informally (Elwood et al. 2009).

On the basis of the success at Shelter Cove, from 2002 to 2016 Airola and Kostka established and encouraged others to erect nest boxes for Purple Martins at six other northern California sites. We selected sites for box installation on the basis of conditions observed at occupied snags and bridges locally and suitable in California generally (Williams 1998, Airola and Williams 2008, Airola 2009) and where landowners were interested. The sites differed in characteristics that may have affected the likelihood of successful colonization, including potential source populations (size and trend, distance) and habitat (openness, potential insect abundance, presence of competitors). Here we summarize results of attempts to supply nest boxes for recovery of Purple Martin populations at seven locations in northern California.

\section{METHODS}

The locations where we installed nest boxes ranged from southern Humboldt County south to Santa Clara County and inland to Sacramento (Figure 1, Table 1). All nest boxes were of the same design as used successfully in the Pacific Northwest (Milner 1988, Figure 2). Boxes were wooden with a single compartment $15 \mathrm{~cm}$ high by $15 \mathrm{~cm}$ wide by $27 \mathrm{~cm}$ deep and a rectangular entrance hole $7 \mathrm{~cm}$ wide and $3 \mathrm{~cm}$ high to discourage entry by starlings. At most sites, we hung boxes $4 \mathrm{~m}$ above ground on a $5-\times 10$ $\mathrm{cm}$ pole (i.e., a " $2 \times 4$ "). At one site (Mt. Umunhum) boxes were mounted on abandoned utility poles. At all sites except one (Greenwood Creek), we 
Table 1 Survey Effort and Locations Where Nest Boxes Were Erected and Monitored for Purple Martins in Northern California

\begin{tabular}{|c|c|c|c|c|}
\hline Site & Years & Specific location & Latitude, longitude & References \\
\hline $\begin{array}{c}\text { Shelter Cove, } \\
\text { Humboldt }\end{array}$ & $2008-11$ & $\begin{array}{c}\text { Rawhide Ct. } \\
\text { Pine Ct. } \\
\text { Combs Ct. } \\
\text { Cantle Ct. } \\
\text { Shaker Rd. } \\
\text { Spring Rd. } \\
\text { Oak Dr. }\end{array}$ & $\begin{array}{l}40.0369,-124.0623 \\
40.0360,-124.0688 \\
40.0230,-124.0406 \\
40.0372,-124.0752 \\
40.0323,-124.0732 \\
40.0411,-124.0736 \\
40.0410,-124.0548\end{array}$ & $\begin{array}{l}\text { Elwood et al. 2009, } \\
\text { Williams 1998, Kostka, } \\
\text { Airola pers. obs. }\end{array}$ \\
\hline $\begin{array}{l}\text { Greenwood } \\
\text { Creek, } \\
\text { Mendocino }\end{array}$ & $2012-14$ & $\begin{array}{l}\text { NW of State Rt. } \\
1 \text { bridge }\end{array}$ & $39.1270,-123.7125$ & $\begin{array}{l}\text { Airola 2009, M. Morris and } \\
\text { S Grimes pers. comm. }\end{array}$ \\
\hline $\begin{array}{l}\text { Navarro } \\
\text { Vineyards, } \\
\text { Mendocino }\end{array}$ & 2011-17 & Main pond & $39.0981,-123.4810$ & Airola pers. obs. \\
\hline $\begin{array}{l}\text { I St. Bridge, } \\
\text { Sacramento }\end{array}$ & $2008-17$ & $\begin{array}{c}\text { California } \\
\text { Railroad } \\
\text { Museum parking } \\
\text { lot }\end{array}$ & $38.5855,-121.5039$ & $\begin{array}{l}\text { Airola and Grantham 2003, } \\
\text { D. Kopp pers. comm., } \\
\text { Airola pers obs. }\end{array}$ \\
\hline $\begin{array}{l}\text { Yolo Bypass } \\
\text { Wildlife Area, } \\
\text { Yolo }\end{array}$ & $2008-17$ & $\begin{array}{l}\text { Between parking } \\
\text { lots A and B } \\
\text { West of parking } \\
\text { lot B } \\
\text { Southwest of } \\
\text { parking lot B }\end{array}$ & $\begin{array}{l}38.5541,-121.6292 \\
38.5498,-121.6292 \\
38.5422,-121.6292\end{array}$ & $\begin{array}{l}\text { J. Zinkl pers. comm., } \\
\text { Airola pers. obs. }\end{array}$ \\
\hline $\begin{array}{l}\text { Davis Core Area } \\
\text { Drainage } \\
\text { Pond, Yolo }\end{array}$ & 2009-17 & $\begin{array}{l}\text { Toad Hollow } \\
\text { Park }\end{array}$ & $38.5473,-121.7276$ & Airola pers. obs. \\
\hline $\begin{array}{l}\text { Mt. Umunhum, } \\
\text { Santa Clara }\end{array}$ & 2014-17 & $\begin{array}{l}\text { Loma Almaden } \\
\text { Rd. }\end{array}$ & $37.1604,-121.9136$ & $\begin{array}{l}\text { Jaramillo } 2012 \text { and pers. } \\
\text { comm., M. Chaney pers. } \\
\text { comm. }\end{array}$ \\
\hline
\end{tabular}

mounted boxes in groups of three spaced 6-40 m apart. In addition, at Shelter Cove, we installed plastic gourds (Supergourds and Troyer horizontal models, available at http://purplemartin.org/shop/).

\section{Study Areas}

Shelter Cove. Shelter Cove (Humboldt Co.) is a small residential coastal community in the remote, rugged King Range. The surrounding region supports one of California's largest population of Purple Martins (Airola and Williams 2008, Airola 2009). Shelter Cove has many snags created in 1973 by the Finley Creek wildfire, which destroyed much of the overstory forest (Robinson 1985, Bureau of Land Management and EDAW 2004, Kostka et al. 2008), and here martins nest in snags left after the fire (Williams 1998). These snags are declining because of rot and removal to reduce fire and safety hazards as the human community expands (pers. obs.). Replacement of large numbers of snags is unlikely under such conditions, and, absent intervention, the availability of cavities suitable for Purple Martin nesting 


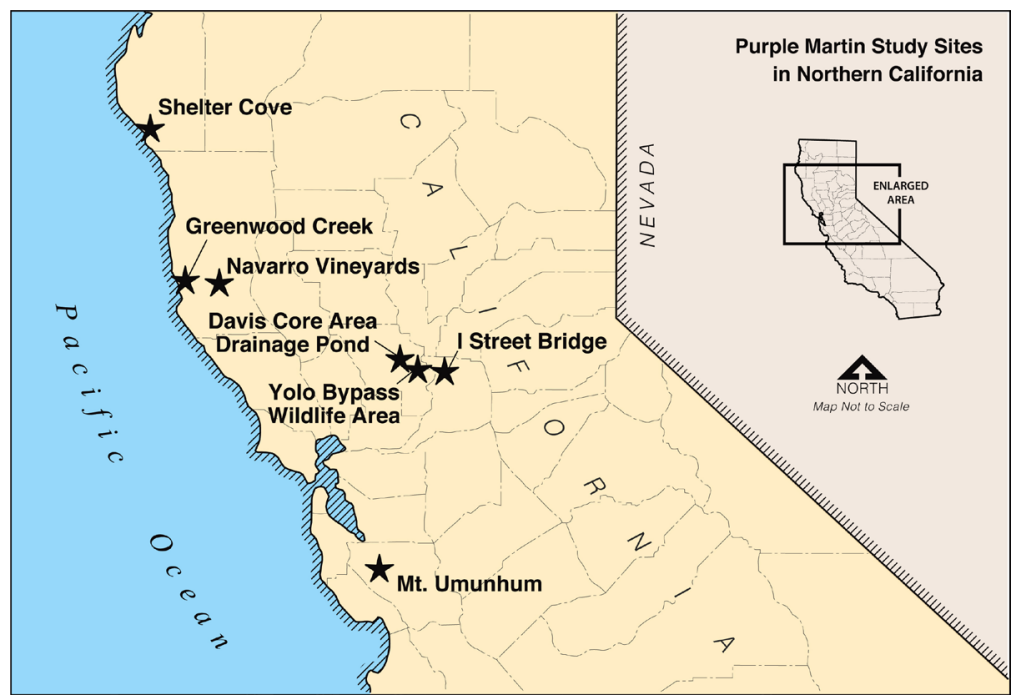

Figure 1. Locations of nest boxes installed for Purple Martins in northern California.

will decline. The area has been extensively subdivided for development and is gradually being built out. Much of the undeveloped area supports thick stands of Douglas-fir (Pseudotsuga menziesii) regenerated since the fire and a scattering of large remnant trees and snags.

The Purple Martin population at Shelter Cove is difficult to estimate accurately, owing to its apparent large size and extent and the site's remoteness, steep topography, and dense vegetation (Airola and Williams 2008, Airola 2009). Bailey et al. (1994) reported " 40 nesting birds" at Shelter Cove in 1994, and Williams (1998) listed nesting-season records for 1990 and 1997, both without detail. On the basis of a survey of less than one day in 2002 , Hill et al. (2004) reported 33 individuals and confirmed six nesting pairs.

In 2002, we placed three nest boxes $15 \mathrm{~m}$ from an active martin nest in a snag (Kostka et al. 2008). In 2008, we added 15 boxes in groups of two to four, each spaced about $6 \mathrm{~m}$ apart at six other sites within 250 ha, in grassy forest openings on middle and upper slopes facing south to west. All sites were within $1 \mathrm{~km}$ of known nests in snags (see Table 1). We also placed seven gourds opportunistically at local residences, near some of which martins were nesting in other substrates. We considered quality of the habitat at these residential sites to be lower than where we erected boxes but placed them there because of concern for vandalism in more open areas. All nest boxes and gourds remained available from 2008 at least through 2011, after which monitoring ended.

Greenwood Creek Bridge. This site on State Route 1 along the Pacific coast near Elk, Mendocino Co., was first reported to be used by breeding martins in 2004 and supported five to ten pairs in 2009 (Airola 2009). The bridge was reconstructed from 2012 to 2014. Prior to construction, the bridge site was mostly overgrown by trees that blocked martins' access 


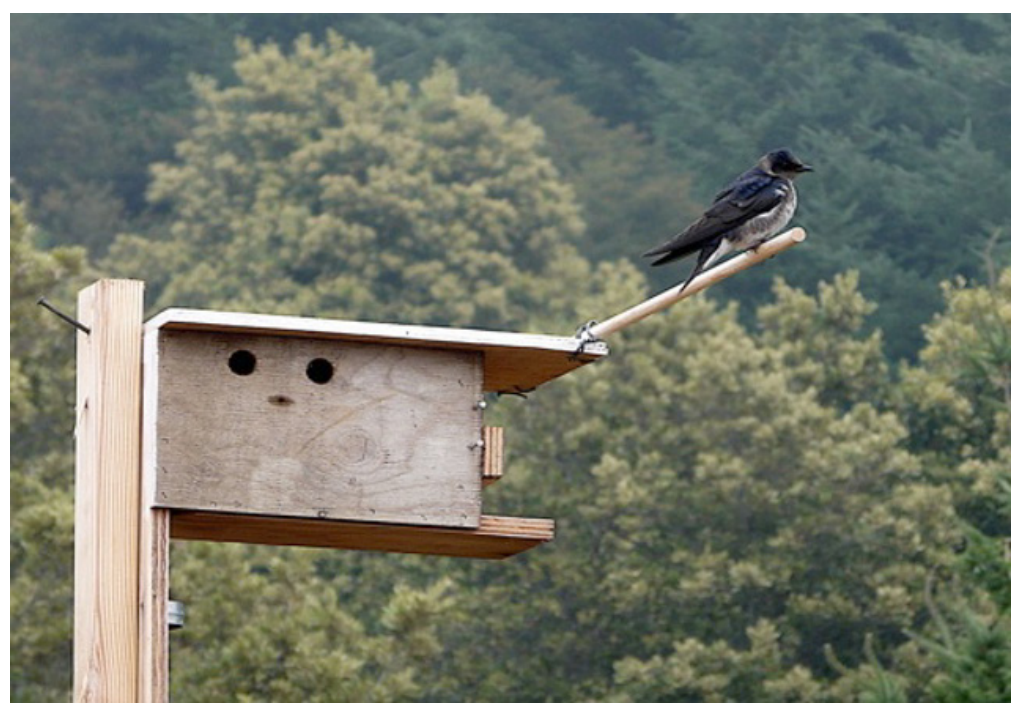

Figure 2. Adult female Purple Martin on next box at Shelter Cove, Humboldt County, California.

Photo by Daniel A. Airola

(Airola 2009), but tree removal during construction reopened it partially. As mitigation for bridge reconstruction, the California Department of Transportation placed six nest boxes about $3 \mathrm{~m}$ apart within $100 \mathrm{~m}^{2}$ near the bridge in 2012. Despite Airola's advice to the contrary, boxes were installed in a low area in the road's right-of-way where the martins' access was impeded by adjacent trees and the bridge.

Navarro Vineyards. Anderson Valley, Mendocino Co., supports a mixture of vineyards, grassland, oak woodland, and several irrigation and frostprotection ponds. A few pairs of martins have regularly nested $2 \mathrm{~km}$ from Navarro Vineyards in snags at Hendy Woods State Park (e.g., records of one to ten individuals at www.ebird.org). The vineyard's staff erected three boxes on the shoreline of a 1.7-ha pond in 2011.

ISt. Bridge. This bridge in Old Sacramento is one of 14 elevated freeways and overpasses in the Sacramento region that have supported Purple Martin colonies since 2002 (Airola and Kopp 2009, 2017). Martins nest in large chambers within concrete bridges, accessed through holes in the bridges' undersides (Airola and Grantham 2003). A population of 29-35 pairs nested in bridges along Interstate 5 at I St. from 2002 to 2005, but it declined to six pairs by 2008 and remained at four to seven pairs through 2014 (Airola and Kopp 2017). A similar decline, from 128 to 23 pairs, occurred during this period at the other colonies in Sacramento bridges (Airola and Kopp 2017). Kostka and Airola erected five next boxes with martin decoys (www. purplemartin.org/shop/product/decoy/purple-martin-decoy/) within $50 \mathrm{~m}$ of the I St. bridge colony in 2008. This colony is also the nearest to the two sites in Yolo County where martin boxes have been installed (see below). 
Yolo Bypass Wildlife Area. This area in Yolo Co. is within a large flood bypass and is managed by the California Department of Fish and Wildlife for water birds and other wildlife (Brice 2015). Land cover consists of seasonal and permanent wetlands and rice fields. We selected the area for box installation despite its 11-km distance from the nearest source population (I St. colony) because of sympathetic management and an abundance of flying insect prey. Also, martins had previously colonized the overpass (next to the Davis Core Area Drainage Pond site), nearly $20 \mathrm{~km}$ from the nearest colony in Sacramento (Airola et al. 2004). In 2008, Kostka and Airola installed 15 boxes with Purple Martin decoys on poles in four groups. During 2008 and 2009, as a further attractant, we placed a recorder that played the Purple Martin's dawn song (Morton 1988) during the mornings. Additional boxes (two per pole) were added at some sites in 2010.

Davis Core Area Drainage Pond. This site is a 1.4-ha stormwaterdetention basin in the city of Davis, Yolo Co., adjacent to an overpass that had been colonized in 2003 by two pairs of martins (Airola et al. 2004) but had not been used subsequently. Three nest boxes were installed in 2008.

Mount Umunhum. Mount Umunhum is a 1144-m peak on the San Francisco Peninsula within Santa Clara Co. Land cover includes coastal chaparral, mixed hardwood-Douglas-fir forest, roads, and former Department of Defense facilities. Purple Martins were identified nesting on the mountain in 2011 , and three to six pairs nested there in 2012, all in utility poles (Jaramillo 2012). The regional martin population is small, dispersed, and declining (Airola 2009). A. Jaramillo (pers. comm.) placed six nest boxes on and adjacent to utility poles along a ridge-top road in 2014. From 2015 to 2017, several of these boxes were removed for road construction, and several others became unsuitable because of lack of maintenance (M. Chaney pers. comm.).

\section{Monitoring}

At Shelter Cove, we monitored boxes and other nest substrates at different frequencies in different years. In 2007, Kostka and Airola checked nest boxes during a single early-season visit in late May. In 2008, Elwood systematically checked all boxes and other nest sites every 14 days from 13 April through 14 August. She estimated nesting pairs on the basis of the frequency and duration of detections at nest sites, examination of boxes, and diagnostic breeding behaviors (Airola and Grantham 2003). We considered a nest successful if nestlings reached 23 days of age (i.e., within 5 days of the average 28-day fledging period; Brown and Tarof 2013). In 2009, Elwood surveyed all boxes and gourds on 16 May and 18 July, determined in 2008 as within the optimal periods for counting pairs and confirming nesting (Airola 2009). Subsequent surveys consisted of single late-season visits by Kostka on 1 and 2 July 2010 and on 27 June 2011 to check all boxes and gourds and incidentally record use of other substrates.

Monitoring at other sites was variable in the number of years surveyed (Table 1) and the frequency of surveys. Multiple visits were made annually to the I St. Bridge, Yolo Bypass, and Davis Core Area Drainage Pond sites. Mt. Umunhum was visited multiple times during the first year after box installation, then monitored once or several times annually during the breeding season. 
Greenwood Creek was intensively monitored only from 2012 to 2014 . The Navarro Vineyards were visited once during the nesting season in most years.

\section{RESULTS}

Shelter Cove. Purple Martins nested in two of five nest boxes at Shelter Cove in 2007 (Kostka et al. 2008) and in five of the 15 boxes available in 2008, including two boxes installed just prior to the 2008 nesting season (Table 2). In total, we detected 18 nesting pairs using a wide variety of substrates in 2008, including snags, utility poles, and buildings, but no gourds. Sixteen (89\%) of 18 occupied nests surveyed for reproductive success in 2008 fledged young, including three of the five in boxes. In 2009, we confirmed nesting at 24 cavities, including 10 nest boxes and one gourd. An estimated 10 additional pairs, some with fledged young, nested in a nearby area where snags were the only nest substrate available. The total of nesting pairs detected increased from 18 to 33 (+83\%) from 2008 to 2009 , despite the reduced survey effort in 2009.

In 2010, 13 of 23 inspected nest boxes and gourds contained Purple Martin eggs, and martins continued to occupy a variety of other cavities, but success was unconfirmed because of lack of access and the early survey date. In brief 2011 surveys, martins were using 10 nest boxes and several other substrates. Given the early dates of the 2010 and 2011 surveys, additional boxes, gourds, and other sites could have been used by later-nesting martins, especially second-year birds, which arrive at colonies and begin nesting later than older martins (Brown and Tarof 2013). From 2008 through 2010, when we surveyed all nest boxes and gourds, Purple Martins used a greater proportion of available boxes $(58 \%)$ than of gourds $\left(14 \% ; \chi^{2}\right.$ 1d.f. $\left.=11.0, p=0.0009\right)$.

\section{Other Sites}

Greenwood Creek Bridge. During reconstruction in 2012, martin access was reduced to half of the bridge, but 10 pairs continued to nest in

Table 2 Number of Pairs of Purple Martins Observed Nesting in Boxes, Gourds, and Other Sites at Shelter Cove, California, 2007-2011 ${ }^{a}$

\begin{tabular}{ccccccc}
\hline Year & $\begin{array}{c}\text { Nest } \\
\text { Box }^{b}\end{array}$ & Gourd & Snag & $\begin{array}{c}\text { Utility } \\
\text { Pole }\end{array}$ & Building & Total \\
\hline 2007 & 2 & NA & NS & NS & NS & 2 \\
2008 & 5 & 0 & 7 & 5 & 1 & 18 \\
2009 & 10 & 1 & $14^{c}$ & 4 & 4 & 34 \\
2010 & $11^{d}$ & 2 & NS & NS & 2 & 15 \\
2011 & 10 & NS & NS & NS & 4 & 14 \\
\hline
\end{tabular}

${ }^{a}$ NA, none available for use; NS, substrate not surveyed.

${ }^{b}$ Five nest boxes were available in 2007 . Seven gourds and 15 boxes were available in 2008 and thereafter.

${ }^{c}$ Nesting in four snags was confirmed through repeated surveys; the other 10 were estimated to have been used based on late-season association of pairs with snags near the main survey area. ${ }^{d}$ Additional boxes found with nesting material but no eggs, including one in 2010 and two in 2011, were not counted as representing nesting pairs. 
the accessible section (S. Grimes pers. comm.). The martins' access to the bridge was eliminated entirely in 2013 (M. Morris pers. comm.). Despite the reduction in availability of nest sites during 2012 and 2013, martins did not occupy nest boxes then or in subsequent years (M. Morris, S. Grimes pers. comm.). After exclusion netting was removed when construction was complete, 10 martin pairs reoccupied the bridge (M. Morris pers. comm.). Each year, Violet-green Swallows (Tachycineta thalassina) nested in some boxes.

Navarro Vineyards. Tree Swallows (Tachycineta bicolor) adopted all nest boxes here the first year they were erected. Swallows, and in some following years House Sparrows (Passer domesticus), occupied all the boxes. We noted martins flying high over the site during the breeding season, but they never nested in the boxes.

I St. Bridge. Although martins from the adjoining bridge colony perched regularly on boxes, they never nested in them from 2008 through 2015, when all boxes but one were removed for a construction project.

Yolo Bypass Wildlife Area. Most of the installed nest boxes were immediately adopted by Tree Swallows and several pairs of House Sparrows and House Finches (Haemorhous mexicanus), which nested in them annually thereafter through 2017. No Purple Martins have been observed on or near the boxes.

Davis Core Area Drainage Pond. The boxes were used by Tree Swallows and Western Bluebirds within the first few years after being installed in 2009 but were never used by Purple Martins.

Mt. Umunhum. No martins nested in nest boxes or utility poles on this mountain in 2014 or 2015 (A. Jaramillo pers. comm.). The nearest area occupied during those years was Mt. Thayer, about $1.6 \mathrm{~km}$ away. In 2016 and 2017, after the loss of some boxes to construction and weathering, none of the few remaining suitable boxes was used, but utility poles were reused by three pairs in both years (M. Chaney pers. comm.).

Characteristics of all seven sites where boxes were set out are summarized in Table 3.

\section{DISCUSSION}

Our study documents the first instance in California in which Purple Martins have been attracted to breed in nest boxes placed for them. Previous reports of nest-box use in California consist of only four records of incidental use at three locations over nearly a century (Williams 1998). At Shelter Cove, martins used a variety of nesting substrates greater than at any other site in California (Williams 1998, Airola 2009), suggesting that natural nest sites were limited and that martins were required to explore novel nesting substrates, such as buildings. Placement of boxes adjacent to existing nest sites or in similar open areas lacking nest sites likely encouraged the boxes' adoption. The rate of use of gourds may have been lower than that of boxes because of their novelty to local martins or placement in less open areas, or simply a preference of local birds to use boxes over gourds. Although we could not determine the total population nesting at Shelter Cove annually, the rapid adoption of newly installed boxes between 2007 and 2009 suggests that the population may have increased here as a result of boxes being installed. 
ATTEMPTS TO ESTABLISH PURPLE MARTIN IN NEST BOXES IN CALIFORNIA

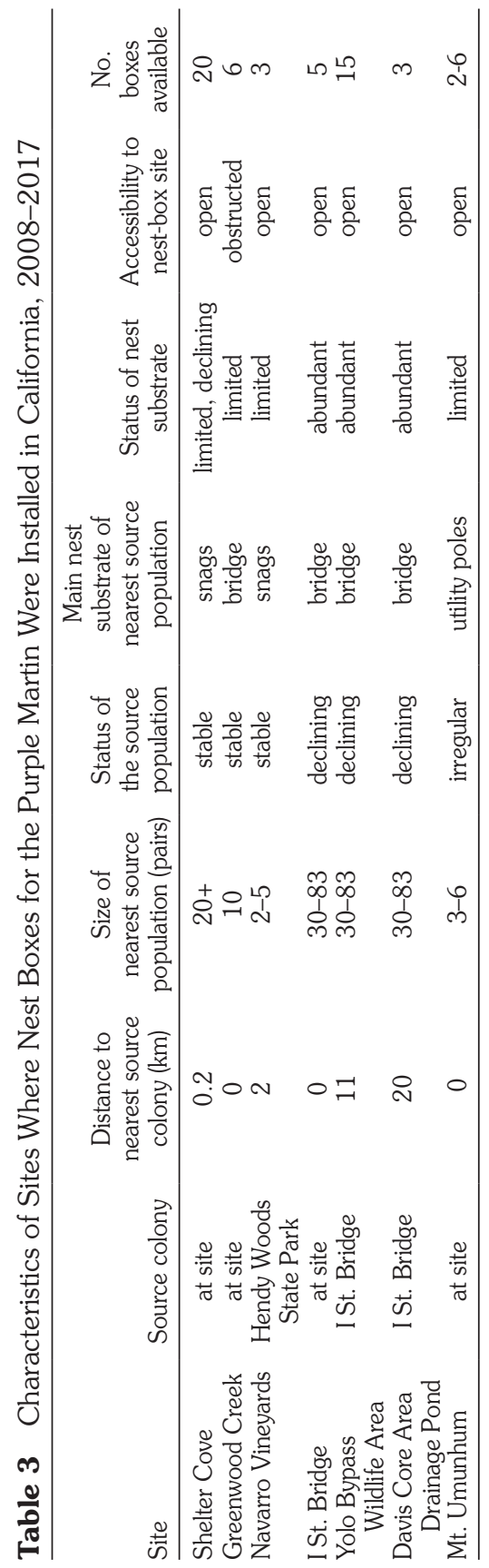


Potential causes for the lack of use of boxes at Greenwood Creek include the dissimilarity of the boxes from nesting sites in bridges, and the placement of the boxes in a low area with obstructed access. In addition, the nearly continuous availability of 15-29 nesting cavities in the bridge may have adequately accommodated the nesting population and thus discouraged adoption of the boxes. Vegetation removal adjacent to the bridge during construction likely made more existing nesting sites available. Competition with other cavity nesters was likely not a factor, as the presence of empty boxes suggests swallows' use of boxes did not discourage occupancy by martins.

Use of Navarro Vineyards may have been discouraged by the small size of the source population, the small number of boxes, and the resulting competition for nest sites. Observations of martins above the site during the breeding season attest to the presence of a source population. Since Tree Swallows and House Sparrows both nest earlier than Purple Martins and are known to compete with them for nest sites (Jackson and Tate 1974, Brown and Tarof 2013), they may have preempted the few boxes there.

In Sacramento, suitable nest sites were superabundant in the I St. Bridge (>160 nesting chambers, Airola and Grantham 2003), yet the population here was declining before boxes were installed and continued to decline through our study (Airola and Kopp 2017). The boxes also were dissimilar in design from the nest sites in bridges. Several of the five nest boxes were occupied annually by House Finches, but over many visits we observed no aggressive interactions that suggested competition for the boxes.

Factors discouraging martin use of Yolo Co. boxes include a substantial distance $(11-20 \mathrm{~km})$ from the closest potential source population in Sacramento, the decline of that population, and difference in nest substrate (i.e., bridge versus box; Airola and Kopp 2017). Although other species occupied most boxes, we saw no Purple Martins near boxes, suggesting competition with other species was not a factor that prevented martin use.

Overall, conditions appeared promising for nest-box use at Mt Umunhum, especially the similarity of the utility-pole nest sites to boxes and the limited number of alternatives. Factors that may have discouraged martin use here during our study were the small number of suitable boxes, the small size and irregularity of the source breeding population, and perhaps the dry conditions that reduced insect prey.

Although artificial gourds were used for the first time in California at Shelter Cove, our opportunistic placement of them prevents us from fully comparing their adoption to that of nest boxes. Martins use gourds extensively in eastern North America (Brown and Tarof 2013), and gourds have been readily adopted in some western areas where boxes were already in use (Fouts 1996, Kostka pers. obs.). We suggest that because they differ more in appearance from existing natural nest sites than do nest boxes, gourds should not be introduced exclusively, but rather should be used either together with nest boxes or after martins have occupied nearby boxes.

Selection of sites for future nest-box projects poses a dilemma. Martins are more likely to adopt boxes where populations are larger and healthier. Establishing a population in boxes, however, may be of greatest conservation value in areas with small populations that are declining because of a lack of nest sites or nest-site competition, and thus where adoption of boxes 
is less likely. Areas where the availability of nest sites is declining, whether from natural processes or human activity, should be priorities for proper installation of boxes, regardless of population size. Although the prospect for success in any one area with a depleted population may be low, multiple attempts over a wide area are still desirable because the species is so seriously reduced over so much of its range (Garrett and Dunn 1981, Airola and Williams 2008, Airola 2009).

We offer the following guidelines for site selection for attempts to establish the Purple Martin in nest boxes as a conservation tool in California and potentially elsewhere in the West where boxes have not been adopted:

- Sites should be near ( $<3 \mathrm{~km}$ from) a sizable ( $>5$ pairs) source population; closer and larger is better.

- The trend of the source population should be positive or stable or the available nest sites should be threatened, whether by physical elimination, obstruction by vegetation, or colonization by competing species.

- Use of boxes at sites where the source populations nests in snags, utility poles, or other sites may be more successful than where the source population uses entrance holes in the undersides of bridges.

- Boxes should be of the single-compartment design (not "apartment style") and placed 5-20 m apart in open terrain where the martins have good flight access.

- At least six boxes should be installed per site (in groups of three) to offer a range of conditions and reduce the potential for competition with other species.

- Ensure that boxes can be managed over time, which includes being cleaned out at least every few years; native competitors can be managed by opening boxes just before the martin's spring arrival, and non-native competitors can be removed, where warranted.

The fate of the Shelter Cove nest boxes after 2011 illustrates the challenges of these attempts and the need to sustain them. The initial program succeeded because of substantial effort to build and transport boxes, gain permission from landowners to place boxes, enlist a small group of resident enthusiasts to monitor and maintain boxes, and recruit a college student (Elwood) to monitor the population consistently and carefully. Many of the resident landowners and helpers were retirees and since 2011 have moved away. The remoteness of the site from our homes (400-1200 km) has prevented us from performing needed maintenance and recruiting additional volunteers. As a result, we are uncertain if the boxes are still being used.

The need for a dedicated team of volunteer Purple Martin "landlords" has long been recognized as critical to the success of nest-box programs (Kostka and McAllister 2005, Tautin et al. 2009, Cousens and Lee 2012). Our inability to transition box management beyond the initial pioneers emphasizes that establishing a sustainable tradition of box management is critical for long-term success. Often, success comes from the dedication and persistence of a single local individual or small group, who recruits, trains, monitors, and supports individual landlords.

The Purple Martin's adoption of nest boxes at Shelter Cove and success elsewhere in the species' range demonstrates that boxes may be useful in securing and recovering Purple Martin populations in California and else- 
where in the West. Successful use of boxes, however, should not diminish the importance of protecting martins at their existing nesting sites in California, whether in trees or bridges. Indeed, our results reemphasize the importance of their conservation.

\section{ACKNOWLEDGMENTS}

We appreciate cooperation of Shelter Cove residents and landowners Sara Wickland, Doug Epperly, Gordon and Billie Switzer, Sharon Donahue, Dan and Connie Paul, Julia George, and Fred Bauer. The Purple Martin Conservation Association (PMCA), U. S. Fish and Wildlife Service's (USFWS) Sacramento Field Office, MidPeninsula Open Space District, and Caltrans provided partial support for travel and monitoring expenses. The Sacramento Audubon Society (SAS) funded materials for Sacramento area boxes and broadcast of dawn song. Betty Warne, Valerie Bloom, and Susan Jones (USFWS), Louise Chambers (PMCA), and Keith Wagner and Tim Fitzer (SAS), among others, assisted in acquiring funds. We thank the many people who provided permission to place boxes: Dave Feliz (Yolo Bypass Wildlife Area), Mark Heda (California State Railroad Museum), Ted Bennett and Deborah Cahn (Navarro Vineyards), Steve Abbors and Meredeth Manning (Mid-Peninsula Open Space District), and John McNerney (city of Davis). Lynn Schmidt, Alvaro Jaramillo, Ed Whisler, John McNerney, Matthew Chaney, David Harr, Sarah Grimes, Joe Zinkl, Monica Morris, and Dan Kopp helped erect and monitor boxes. Kevin Thomas installed and operated the dawn-song player at the Yolo Bypass. James Hill III (Bird Abodes) and Ken Kostka (Purple Martin Preservation Alliance) donated gourds and decoys. John Tautin, Tom Gardali, Ed Pandolfino, Daniel Cooper, Frank Fogarty, and Philip Unitt provided valuable comments on the manuscript.

\section{LITERATURE CITED}

Airola D. A. 2009. Status of the Purple Martin in northern California: Results of a pilot study to develop and apply a survey method. Report to U. S. Fish and Wildlife Service, 2800 Cottage Way, Sacramento, CA 95825.

Airola, D. A., and Grantham, J. 2003. Purple Martin population status, nesting habitat characteristics, and management in Sacramento. W. Birds 34:235-251.

Airola, D. A., and Kopp, D. 2009. Recent Purple Martin declines in the Sacramento region of California: Recovery implications. W. Birds 40:254-259.

Airola, D. A., and Kopp, D. 2017. Status of the Sacramento Purple Martin breeding population in 2016: Yet more decline. Central Valley Bird Club Bull. 20:18-23.

Airola, D. A., and Williams, B. D. C. 2008. Purple Martin (Progne subis), in California bird species of special concern: A ranked assessment of species, subspecies, and distinct populations of birds of immediate conservation concern in California (W. D. Shuford and T. Gardali, eds.), pp. 293-299. Studies of Western Birds 1. W. Field Ornithol., Camarillo, CA, and Calif. Dept. Fish and Game, Sacramento.

Airola, D. A., Kopp, D., and Kostka, S. 2004. Purple Martin population status and colonization patterns in the Sacramento region in 2004. Central Valley Bird Club Bull. 7:71-77.

Airola, D. A., Cousens, B, and Kopp, D. 2014. Accelerating decline of the Sacramento Purple Martin breeding population in 2014: What are the possible causes? Central Valley Bird Club Bull. 17:12-22.

Bailey, S. F., Fix, D., and Yee, D. G. 1994. Middle Pacific coast region. Natl. Audubon Soc. Field Notes 48:984-987.

Brice, A. 2015. The Yolo Bypass Wildlife Area: History, management, and significance for birds. Central Valley Bird Club Bull. 18:2-13

Brown, C. R., and Tarof, S. 2013. Purple Martin (Progne subis), in The Birds of 
North America Online (P. G. Rodewald, ed.), no. 287. Cornell Lab Ornithol., Ithaca, NY; doi 10.2173/bna.287.

Bureau of Land Management and EDAW. Inc., 2004. King Range National Conservation Area. Proposed resource management plan and final environmental impact statement. U. S. Dept. Interior, Bureau of Land Management, Arcata Field Office, Arcata, CA.

Cousens, N. B. F., and Lee, J. C. 2012. Status report on the Western Purple Martin (Progne subis arboricola) in British Columbia. Report to the British Columbia Ministry of Environment, Victoria, BC.

Elwood, C., Wickland, S., Kostka, S., and Airola, D. A. 2009. Success continues for pilot nest box program at Shelter Cove, California. Purple Martin Update 18(2):27-29.

Fouts, D. R. 1996. Ten years helping Purple Martins in the Pacific Northwest. Purple Martin Update 1(1):7-11.

Garrett, K., and Dunn, J. 1981. Birds of Southern California: Status and Distribution. Los Angeles Audubon Soc., Los Angeles.

Gowaty, P. A., and Plissner, J. H. 2015. Eastern Bluebird (Sialia sialis), in The Birds of North America Online (P. G. Rodewald, ed.), no 381. Cornell Lab Ornithol., Ithaca, NY; doi 10.2173/bna.381.

Guinan, J. A., Gowaty, P. A., and Eltzroth, E. K. 2008. Western Bluebird (Sialia mexicana), in The Birds of North America Online (P. G. Rodewald, ed.), no. 510. Cornell Lab Ornithol., Ithaca, NY; doi 10.2173/bna.510.

Hill, J. R. III, Kostka, S., and Kostka, K. J. 2004. The snag nesting Purple Martins of California, Oregon, and Washington. Purple Martin Update 13(1):1-7.

Horvath, E. 1999. Distribution, abundance, and nest site characteristics of Purple Martins in Oregon. Ore. Dept. Fish and Wildlife Rep. 99-1-01.

Jackson, J. A., and Tate, J., Jr. 1974. An analysis of nest box use by Purple Martins, House Sparrows, and Starlings in eastern North America. Wilson Bull. 86:435-449.

Jaramillo, A. 2012. Avian resources on Mt. Umunhum (June 2012 data). Report to Midpeninsula Regional Open Space District, 330 Distel Circle, Los Altos, CA 94022.

Kostka, S., and McAllister, K. 2005. Purple Martin, in Birds of Washington, Status and Distribution (T. Wahl, B. Tweit, and S. Mlodinow, eds.), pp. 269-270. Ore. State Univ. Press, Corvallis.

Kostka, S., Airola, D. A., and Switzer, G. 2008. Recent use of nest boxes by Purple Martins in northern California. Purple Martin Update 17(3):13-15.

Marti, C. D., Poole, A. F., and Bevier, L. R. 2005. Barn Owl (Tyto alba), in The Birds of North America Online (A. Poole, ed.), no. 1. Cornell Lab Ornithol., Ithaca, NY; doi 10.2173/bna.1.

Milner, R. L. 1988. Guidelines for establishing and maintaining a Purple Martin nest colony. Wash. State Dept. Fish and Wildlife, Olympia, WA.

Morton, E. S. 1988. Dawnsong of the Purple Martin. Atlantic Nat. 38:38-48.

Robinson, O. L. 1985. The Finley Creek fire storm on September 8, 1973 in Humboldt County, California. Proc. Conf. Fire and Forest Meteorol. 8:17-23.

Tautin, J., Cousens, B., Kostka, K., Kostka, S., and Airola D. 2009. Addressing regional declines in Purple Martin populations, in Tundra to Tropics: Connecting Birds, Habitats, and People (T. D. Rich, C. Arizmendi, D. W. Demarest, and C. Thompson, eds.), pp. 82-87. Proc. 4th Int. Partners in Flight Conf. Partners in Flight, McAllen, TX.

Williams, B. D. C. 1998. Distribution, habitat associations, and conservation of Purple Martins in California. M.S. thesis, Calif. State Univ., Sacramento. 